\title{
Um Cristão Em Tempos De Cólera: a crônica política de Alceu Amoroso Lima
}

\author{
A christian in the time of cholera: the political chronicle of Alceu Amoroso Lima
}

\section{Marcelo Timotheo da Costa}

Doutor em História

Professor da Universidade Salgado de Oliveira marcelotimotheo@uol.com.br

Resumo: O presente texto analisa as colunas jornalísticas que o intelectual católico Alceu Amoroso Lima (1893-1983) escreveu entre 1964 e 1977. Corte temporal que abrange o período que vai dos dias seguintes à implantação da mais recente ditadura brasileira até o final do período de maior repressão do mesmo regime. Quer-se demonstrar aqui que a atuação jornalística de Amoroso Lima fundamentou-se em sua fé cristã, sendo por ela guiada. Deseja-se igualmente ilustrar como a mencionada ação de Alceu Amoroso Lima na imprensa, por sua ampla difusão, tornou nosso autor das mais conhecidas figuras de oposição ao regime ditatorial imposto ao país após março de 1964.

Palavras-chave: Intelectuais católicos, ditadura no Brasil, Alceu Amoroso Lima.

\begin{abstract}
The present text seeks to analyze the newspaper columns written by the Brazilian Catholic intellectual Alceu Amoroso Lima (1893-1983) from the very first days that followed Brazil's 1964 military coup d'état to 1977 - when the most repressive period of the dictatorship established by the aforementioned coup started to be overcome. It is our aim to demonstrate that Amoroso Lima's Christian faith inspired and guided his public critical opinions towards his nation's military rule. Furthermore, we also intend to illustrate how the widespread diffusion of Amoroso Lima's journalist texts had been important to make him one of the most well-known opposition figures during Brazil's last dictatorship.

Keywords: Catholic intellectuals, dictatorship in Brazil, Alceu Amoroso Lima.
\end{abstract}




\section{Introdução}

Serão analisadas aqui as colunas jornalísticas que o intelectual católico Alceu Amoroso Lima (1893-1983) escreveu ao longo do governo ditatorial originado pelo golpe civil-militar de 31 de março de 1964. Para tanto, lança-se luz sobre os textos que Amoroso Lima elaborou entre abril daquele ano e junho de 1977, isto é, entre os dias imediatamente seguintes à deposição de João Goulart e meados do governo de Ernesto Geisel, quando se iniciou a distensão "lenta, gradual e segura" rumo ao restabelecimento do Estado de Direito.

Deseja-se, assim, revisitar a atuação de Amoroso Lima na imprensa durante a fase de implantação do governo de exceção e o subsequente e extenso período mais duro do mesmo. Em movimento complementar, pretende-se igualmente expor como a referida atuação - inequivocamente crítica da ditadura, enfoque esse baseado na fé cristã de nosso autor - contribuiu de maneira decisiva para confirmar, frente a segmento importante do público leitor nacional, a transformação religiosa e política pela qual Alceu passara anos antes. Enfim, é de tal câmbio interior operado por Amoroso Lima e de suas implicações públicas, conforme consignado nas páginas impressas de jornal, em tempos de tormenta, que tratam as linhas seguintes.

\section{1) $O$ tribuno e suas circunstâncias: seis décadas de presença jornalística}

Alceu Amoroso Lima construiu, por sessenta e quatro anos, uma das mais duradouras presenças em colunas jornalísticas, no século XX brasileiro.

Iniciou carreira, como crítico literário, em O Jornal, no ano de 1919. À época, ele dirigia a tecelagem Cometa, empresa familiar fundada por seu pai, Manoel Amoroso Lima. O temor de ser tomado como empresário por demais diletante levou o então jovem articulista a optar por assinar seus textos como Tristão de Athayde. ${ }^{1}$ Permaneceu em $O$ Jornal até 1946; o pseudônimo acompanhou-o até a morte.

Portanto, a presença de Amoroso Lima na imprensa é inaugurada sob o signo dos debates literários. Contudo, será a escolha religiosa de nosso autor, realizada em idade madura, quase uma década após a citada estreia jornalística, que irá inspirar e conduzir

\footnotetext{
${ }^{1}$ A necessidade de um pseudônimo é, pois, explicada por razão práticas. Já a escolha do pseudônimo em particular - Tristão de Athayde - parece não haver tido qualquer razão especial.
} 
sua ação posterior. Alceu converteu-se ao catolicismo, em 1928, aos 35 anos incompletos. Fé que, uma vez assumida, mantém-se por toda a vida. Porém, se Amoroso Lima permaneceu católico da conversão à morte, ocorrida mais de meio século após a eleição do credo religioso, ele cambiou sobremaneira sua forma de entender a fé e as consequências políticas da mesma. De novo: se Alceu não alterou sua pertença à Igreja latina, ele modificou suas interpretações do cristianismo e da relação deste (e do fiel cristão) com o mundo.

Assim, nos 15 ou 20 anos que se sucederam à conversão de nosso intelectual, ele abraçou o ideário católico romano de então, reagindo aos tempos modernos e comungando de eclesiologia cruzadista e triunfalista. Coerente com tal visão de mundo, Amoroso Lima se relacionou com a sociedade contemporânea de forma inflexível. É o tempo do Alceu líder do laicato nacional e campeão da ortodoxia. Ou, mais exatamente, o campeão de dada ortodoxia, definida no Concílio de Trento (1545-1563) e transportada tardiamente aos Trópicos, pelo episcopado brasileiro, desde meados do século XIX. ${ }^{2}$ É o tempo do Alceu que atua como cruzado do "projeto de neocristandade", expressão consagrada na historiografia para crismar a plataforma católica daquele período, ou seja, a intenção de marcar ostensivamente a presença da Igreja em múltiplas esferas da sociedade.

Uniam-se, em tal projeto, reação e proposição. Reação a muitos aspectos que a Igreja Católica percebia como negativos na modernidade: laicismo, indiferença religiosa, materialismo, ameaça esquerdista. Em face de tal conjuntura, a proposta era contra-atacar, replicando o século. Isto é, responder aos desafios da contemporaneidade, E também reproduzir importantes características da sociedade hodierna, cristianizando-as. Sob essa ótica, se, no Brasil, havia, p. ex., associações, sindicatos, universidades e imprensa seculares, deveriam igualmente existir associações, sindicatos, universidades e meios de difusão da informação católicos. O mesmo valia para a intelectualidade. E o neoconverso Alceu aceitou o chamado da hierarquia, que o constituiu líder do laicato nacional, aquele que deveria defender as demandas católicas na praça pública.

Para ilustrar a ação frenética de Amoroso Lima em prol da fé que adotara, recordese que, em sua primeira década após a conversão, ele publicou nada menos que 24 livros. Entre eles, Introdução à Economia moderna (1930), Debates pedagógicos e Preparação à Sociologia (ambos de 1931), Introdução ao Direito moderno (1933), Pela Ação

\footnotetext{
${ }^{2}$ Para breve exposição da experiência católica nacional, ver COSTA, 2010.
} 
Católica (1935), Indicações políticas (1936), O Espírito e o mundo (1936), Idade, sexo e tempo (1938). São obras que chamam atenção por traduzirem fielmente o pensamento típico da neocristandade, seja ele aplicado a áreas do saber específicas, seja pela convocação mais geral dos fiéis católicos à ação no mundo. ${ }^{3}$

A partir de meados da década de 1940 e em movimento mais claramente discernível nos anos 1950, de forma tensa e não-linear, Alceu foi redefinindo sua visão da fé católica e seu entendimento sobre as implicações da mesma para os crentes. Processo interior que repercutiu notavelmente na sua atuação pública - em muito informado pela reflexão católica produzida na França, principalmente por Jacques Maritain, Emmanuel Mounier, Pierre Teilhard de Chardin e Yves-Marie Congar. Ao último, o brasileiro atribuiu a redação de texto decisivo na sua trajetória: "Dieu, est-Il à Droite?" ("Deus está à Direita?"), contundente crítica ao atrelamento do catolicismo a regimes de direita, trabalho publicado, em 1936, pela revista dominicana francesa La Vie Intellectuelle. ${ }^{4}$ Também de relevo para a aludida transformação foram as longas viagens empreendidas por Alceu no início dos anos 1950: à Europa, no ano inaugural desta década, onde ele se encontrou com intelectuais cristãos renovadores; e aos EUA, país no qual permaneceu, entre 1951-53, como diretor do Departamento Cultural da União Pan-Americana, órgão executivo da OEA. Em Washington, Amoroso Lima testemunhou o macartismo, considerando-o grave ameaça à democracia norte-americana, condenando igualmente a associação entre cristianismo e anticomunismo. Anos antes (1946), a propósito, ele

\footnotetext{
${ }^{3}$ Amoroso Lima não apenas expressou por escrito seu apoio ao projeto de neocristandade. No mesmo período temporal, ele acumulou as direções do Centro D. Vital e da revista A Ordem, instituição e periódico que buscavam congregar intelectuais em torno das propostas de neocristandade; ajudou na criação do Instituto Católico de Estudos Superiores, futura PUC-Rio; fundou e presidiu a Liga Eleitoral Católica, presidindo também a Junta Nacional da Ação Católica; foi reitor interino da Universidade do Brasil. Nesta, se opôs à admissão de profissionais de esquerda, ou tomados como simpatizantes dos ideais esquerdistas.

${ }^{4}$ Provavelmente por seu conteúdo polêmico, sobretudo na década de 1930 de acentuada polarização ideológica, "Dieu, est-Il à Droite?" foi, na verdade, publicado sem menção de autoria, nos números de fevereiro e março de 1936 da La Vie Intellectuelle. Dois trechos desse documento são particularmente incisivos. O primeiro deles é: "Evitemos, pois, identificar a Direita e o catolicismo. As condições históricas infelizmente favoreceram este equívoco, que tem sua gênese na origem dos partidos republicanos e foi motivado pela constante hostilidade da esquerda para com a Igreja. Mas se o equívoco, por mais explicável que o seja, é nefasto, teremos razão de perpetuá-lo?" (SEM AUTOR, 1936: 64; edição de fevereiro.) E o segundo: "Uma estranha perversão instalou-se em certos espíritos. Diríamos que confundem a Direita e a Esquerda políticas com a Direita e a Esquerda do Pai no dia terrível do Juízo. Então, os que estiveram à direita aqui embaixo, adiantar-se-iam com passo decidido em direção à Direita do Pai, enquanto os partidários da Esquerda, aturdidos, não teriam outro recurso senão precipitar-se entre os desgraçados. Mas muitos dos que se crêem dentro, estão fora, e muitos dos que parecem fora, estão dentro. Não antecipemos a divisão entre bons e maus." (SEM AUTOR, 1936: 245; edição de março; os trechos foram traduzidos livremente por mim.) Para análise da recepção amorosiana de "Dieu, est-Il à Droite?" ver COSTA, 2008: 183-212.
} 
redigira carta aberta, desaprovando a iniciativa de tornar ilegais as atividades do Partido Comunista Brasileiro, indispondo-se com católicos conservadores. ${ }^{5}$

Assim, em percurso lento, nosso autor vai abraçando teses mais liberais na Igreja e na política. Posicionamento que se torna evidente nos anos 1960. Nesta década, Amoroso Lima irá defender enfaticamente as resoluções do Concílio Vaticano II (1962-1965). Decisões que promoveram o chamado aggiornamento católico, a abertura da Igreja ao espírito moderno. No cenário interno nacional, Alceu apoiou causas como as Reformas de Base pregadas pelo presidente João Goulart e o voto dos analfabetos. E, quanto à política internacional, denunciou a ingerência norte-americana em Cuba e a participação dos Estados Unidos na Guerra do Vietnã, ação que classificou de "genocídio" promovido pela alta tecnologia. ${ }^{6}$

Tal como ocorreu na época em que Amoroso Lima encarnava o fiel paradigmático da neocristandade, sua transformação em crente liberal e pluralista também foi fartamente documentada em livros e artigos na imprensa. Ele, deixando O Jornal, passou a publicar textos, a partir de 1947, no Diário de Notícias, tendo suas colunas transcritas na Folha da Manhã (São Paulo), em O Diário (Belo Horizonte), em A Tribuna (Recife), no Correio do Povo (Porto Alegre) e também no Diário Ilustrado (Lisboa). O vínculo com o Diário de Notícias manteve-se até 1966. E, de 1958 a 1983, Amoroso Lima teve trabalhos veiculados pelo Jornal do Brasil. Ao longo do referido período, suas colunas, publicadas duas vezes por semana no diário carioca, eram reproduzidas na Folha de São Paulo. ${ }^{7}$ É nessa dupla de jornais que o intelectual em lume expressará sua oposição ao mais recente governo ditatorial brasileiro. Atuação que consolidará sua (nova) imagem progressista não apenas entre seus tradicionais leitores católicos, mas o projetará como a voz da liderança leiga cristã e democrática entre o público externo aos muros eclesiais.

\footnotetext{
${ }^{5}$ Documento intitulado "Carta aos Católicos de Maceió”, veiculado na imprensa e na revista A Ordem. Ver AMOROSO LIMA, 1946.

${ }^{6}$ Cf. in AMOROSO LIMA, 1973: 276.

${ }^{7}$ Alceu Amoroso Lima teve ainda relativamente curta passagem por A Tribuna da Imprensa (1950-54), jornal que ajudara Carlos Lacerda a fundar e do qual vai se desligar poucos anos depois, motivado por conflitos com o político udenista. $\mathrm{O}$ distanciamento entre os dois irá se acentuar no futuro, à medida que o intelectual católico for confirmando seus posicionamentos progressistas. Amoroso Lima teve ainda trabalhos veiculados no Jornal da Bahia, Jornal do Commercio e no La Prensa, de Buenos Aires.
} 


\section{2) A Crônica do Tempo Presente}

Em 1977, Alceu Amoroso Lima publicou o livro Revolução Suicida: testemunho do tempo presente. Ali, em texto introdutório, ele afirma que a obra vem complementar quatro outros títulos, todos editados após a queda de João Goulart. Tais volumes coligem colunas veiculadas no Jornal do Brasil (e repetidas na Folha de S. Paulo) onde Amoroso Lima aborda assuntos nacionais e internacionais os mais diversos. No entanto, se a pluralidade temática é privilegiada no conjunto de cinco livros em questão, neles se destaca a oposição sistemática de Alceu à ditadura civil-militar brasileira. Ou, nas palavras do próprio autor, "predomina [...] uma contestação ao movimento de 1964" (AMOROSO LIMA, 1977: 15). Ele se referia aos livros: Revolução, reação ou reforma? (editado em 1964, reunindo colunas de jornais publicadas entre 1958-64), Pelo humanismo ameaçado (1965, artigos de 1962-64), A experiência reacionária (1968, textos de 1964-66), Em busca da Liberdade (1974, colunas de 1967-73) e Revolução suicida (1977, matérias de 1973-77). ${ }^{8}$ A tal coleção, Amoroso Lima deu o título "Crônica do Tempo Presente". Ela vai fornecer as fontes para a análise contida nas linhas seguintes. ${ }^{9}$

Em primeiro lugar, note-se que os dias que sucedem ao golpe de Estado que depôs Goulart encontram um observador cauteloso. Em abril de 1964, Amoroso Lima inicia seu discurso nestes termos: "Perguntam-me: que pensa do movimento de 30 de março?" (1999: 305) $)^{10}$

Como se vê, a estratégia discursiva é coloquial, característica, aliás, da crônica. ${ }^{11}$ E, em sua Crônica do Tempo Presente, Amoroso Lima aborda questões graves, posicionando-se enquanto "conversa" com os leitores. Além de informal, seu tom é prudente. Precaução que o faz reportar-se, na acima citada coluna, a texto escrito meses antes (10/01): “Todo ato, presidencial ou parlamentar, governista ou oposicionista, civil

\footnotetext{
${ }^{8}$ As três primeiras obras foram publicadas pela editora carioca Tempo Brasileiro. Em Busca da Liberdade saiu pela Paz e Terra, do Rio de Janeiro. Já Revolução Suicida foi editada pela Brasília/Rio (RJ). Trabalhei com a primeira edição de todos os livros à exceção de Revolução, Reação ou Reforma - neste caso, utilizei sua reedição pela Vozes (Petrópolis, 1999).

${ }^{9}$ Preferi lançar mão dos artigos jornalísticos reunidos em livro por duas razões: eles são de acesso mais rápido e, principalmente, porque esses mesmos textos foram objeto de seleção realizada pelo próprio Amoroso Lima, sendo, pois, o material mais representativo do período em questão segundo o autor aqui analisado.

${ }^{10}$ Como dito acima, utilizo a segunda edição dessa obra.

${ }^{11}$ Para maior detalhamento sobre o gênero narrativo conhecido por crônica, ver ARRIGUCCI JR., 1987: 51-66.
} 
ou militar, direitista ou esquerdista, golpista ou antigolpista para a correção ou por prevenção contra o possível, é um golpe de morte em nossa vida nacional, em nossa frágil árvore das liberdades públicas” (1999: 305, grifo do autor).

Alceu lamenta a ruptura da "continuidade jurídica do regime e [d]a legalidade", embora afirme que o governo deposto também tenha atentado conta as mesmas "com seus últimos atos", sem explicitá-los todavia (para ambos os trechos, 1999: 305). Ele encontra consolo por não ter sido deflagrada uma guerra civil, constatando que "Ficou provada [...] a lei fundamental de nossa historiografia política: a solução incruenta de nossas crises mais graves." (AMOROSO LIMA, 1999: 306) ${ }^{12}$

Transcorrido pouco tempo, o cenário traçado pelo intelectual católico é bem mais sombrio. A nova ordem não completara sequer um mês e ele dizia, em abril de 1964, temer extremismos:

O perigo que nos ameaça, no momento, é precisamente essa gangorra política. Assim como o regime de JG [João Goulart] caiu por ter se inclinado perigosamente para a esquerda, estamos agora ameaçados de pender para o pólo oposto, na base das tendências extremistas dominantes. Ora, a ação reacionária é tão perigosa e unilateral como a ação revolucionária (AMOROSO LIMA, 1999: 309).

São temores que se cumprem rapidamente. No mês seguinte, Amoroso Lima, de sua tribuna, acusa aquilo que chama, no título de seu artigo, de "Terrorismo Cultural", texto motivado pelas primeiras sanções do novo regime a seus críticos. Ele denuncia, então,

[...] os processos mais antidemocráticos de cassar mandatos, suprimir direitos políticos, demitir juízes e professores, prender estudantes, jornalistas e intelectuais em geral, segundo a tática primária de todas as revoluções que julgam domar pela força o poder das convicções e deter a marcha das idéias (AMOROSO LIMA, 1999 [maio de 1964]: 319-320).

\footnotetext{
${ }^{12}$ Nesta linha de raciocínio (bastante difundida e discutível aliás), acontecimentos como a Guerra dos Farrapos e a repressão a Canudos de Antônio Conselheiro seriam exceções que confirmam tal regra (AMOROSO LIMA, 1999: 306-07).
} 
Seguindo sua argumentação e sendo mais específico, Amoroso Lima nomeou as sanções sofridas por Anísio Teixeira, contra quem nosso autor se opusera determinantemente na década de 1930, ao liderar a reação católica à pedagogia escolanovista; por Josué de Castro e Celso Furtado, afastados de seus cargos pelo governo federal; e as detenções de Ubaldo Puppi, filósofo do Paraná, e do sociólogo Luiz Alberto Gómez de Souza, apresentado como uma jovem liderança intelectual do país. Interessante notar que Alceu, em carta a Maria Teresa, sua filha monja enclausurada, afirma ter recebido, por conta de "Terrorismo Cultural", telefonema do próprio Castello Branco. Ao longo da chamada telefônica, o presidente da República atribuiu o posicionamento do líder católico à suposta má-informação deste sobre o alcance da "penetração comunista" no país" (AMOROSO LIMA, 2003: 400). Observe-se, em acréscimo, que, exatamente dois anos passados da publicação de "Terrorismo Cultural", seu autor, em texto intitulado “Terrorismo Mascarado", volta ao tema, ao comentar declarações de Castello Branco e de Costa e Silva, seu sucessor indicado:

Quando o futuro Presidente da República, nomeado à revelia do povo, nega terminantemente a Anistia, está prolongando o terrorismo cultural; quando o Presidente da República em exercício declara que toda a inquietação ou a agitação da mocidade é fruto de manobras comunistas, está fazendo terrorismo cultural (AMOROSO LIMA, 1966 [maio]: 400).

Denúncia recorrente: $\log$ a após "Terrorismo Cultural”, Alceu já assinara "Primarismo Cultural", texto de 25 de setembro de 1964, onde demonstrou sua indignação pelo "violento expurgo" ocorrido na Universidade de São Paulo, que atingiu docentes como Florestan Fernandes, e pela exoneração de Ernani Maria Fiori, no Rio Grande do Sul (AMOROSO LIMA, 1965: 253-55). Tudo isso, disse Alceu, “[...] provoca uma revolta de consciência, que vai minando cada vez mais, especialmente na mocidade e meios intelectuais, a já escassa popularidade da Revolução de abril.” (AMOROSO LIMA, 1965: 254.)

Vale notar variação na terminologia usada para classificar a deposição de Goulart. Por vezes, nosso autor se refere ao ocorrido como "Revolução" (nem sempre com letra maiúscula), termo empregado pela propaganda do novo governo. O que não significa alinhamento de Amoroso Lima com a retórica oficial. Antes ao contrário, ele indica a banalização do termo "revolução" pela "semântica do primarismo ou do oportunismo 
atual." O tom é mantido adiante, no mesmo texto: "Hoje a bandeira amorfa da revolução cobre tudo." (Para ambos o trechos, ver AMOROSO LIMA, 1974: 29, texto de junho de 1967.) Em outra ocasião, em 27 de abril de 1967, o articulista cristão já fora incisivo: "[...] como se sabe essa palavra ["revolução"] passou a significar no Brasil, a partir de 64, o oposto do que consignam os dicionários” (1974: 23).

E no caso da expressão "Revolução de abril" disposta anteriormente? Nela, o termo "Revolução" ganha complemento cronológico aparentemente neutro. Aparentemente, pois, ao remeter o golpe de Estado para abril, Amoroso Lima não apenas negava a sua data oficial (31/03) como, de forma implícita (mas efetiva), associava-o ao início do mês seguinte. Mais exatamente, ao dia $1^{\circ} \cdot$ de abril, considerado dia mundial da mentira.

A crítica podia ser mais direta: em algumas ocasiões, Alceu se referiu ao mesmo evento como "abrilada" (1965: 208, 222 e 224). Ou, sendo ainda mais explícito, rotulou o acontecido como "movimento de 1 de abril" (1965: 213). Observações semelhantes transformando a "Revolução de março" em "golpe militar" dado em abril (a menção a este mês tem sempre notação negativa) - estão distribuídas na Crônica do Tempo Presente. ${ }^{13}$ E, no artigo "Cara ou Coroa", de dezembro de 1965, seu autor é taxativo, caracterizando o governo constituído como a "Ditadura instalada a $1^{\circ}$. de abril" (1968: 204).

Ditadura a qual Alceu fará intensa oposição, como já foi observado. Cabe, agora, dar mais alguns exemplos de sua intervenção na arena pública, naquele período.

Da tribuna jornalística por ele assinada - presença amplificada posteriormente na edição dos livros que compõem a Crônica do Tempo Presente -, Alceu manifestou-se contra os seguidos Atos Institucionais baixados pelo governo ${ }^{14}$ e execrou a Lei de Segurança Nacional. ${ }^{15}$

O intelectual católico também indagou pelo paradeiro do ex-deputado Rubens Paiva. ${ }^{16}$ E, do mesmo modo, outros desaparecidos menos célebres tiveram sua vez:

\footnotetext{
${ }^{13}$ Cf., p. ex., in AMOROSO LIMA, 1968: 55, 182 e 270. Ver também in AMOROSO LIMA, 1974: 58 e 77.

${ }^{14}$ Cf., p. ex., em AMOROSO LIMA, 1999: 326 (coluna jornalística de maio de 1964); 1965: 279 (20/11/64); 1968: 176-78 (11/11/65) e 1974: 125 (13/02/70), onde Alceu critica, no caso dos dois primeiros textos, o Ato Institucional I e, nos dois últimos textos, os Atos Institucionais II e V.

15 Lei apresentada como "famigerada" e "desgraçada" - citando apenas duas adjetivações a ela remetidas (cf. in AMOROSO LIMA, 1974: 19-20, 13/04/67).

16 AMOROSO LIMA, 1977: 92 (texto original de 13/02/76). Pergunta, aliás, que já havia sido feita na coluna "Trágica Interrogação", veiculada pelo Jornal do Brasil, em 25/02/1971, e não reeditada em livro.
} 
Há neste momento, no Brasil, sem que sequer se possa citar-lhes os nomes, ao lado de nós, dezenas de lares e neles centenas de corações, que sofrem em silêncio a tragédia da espera, da dúvida sobre a vida ou a morte dos seus mais queridos [...] passam os dias, passam os meses, passam os anos talvez, e a espera continua vã. As promessas [das autoridades] continuam vãs. O destino dos desaparecidos continua envolto no mistério. [...] Até quando haverá, no Brasil, mulheres que não sabem se são viúvas; filhos que não sabem se são órfãos [...]? (AMOROSO LIMA [25/10/74], 1977: 45-46).

Alceu Amoroso Lima também ousou defender religiosos dominicanos acusados pelo novo regime de ligações com a guerrilha - situação que causava embaraço e, em alguns casos, constrangedores silêncios na hierarquia católica. ${ }^{17}$ Basta recordar que D. Lucas Moreira Neves, também religioso dominicano, à época bispo auxiliar de São Paulo, esquivara-se de confirmar, em depoimento à Justiça Militar, as torturas sofridas por um destes religiosos (e seu confrade), Frei Tito de Alencar Lima, na prisão. ${ }^{18}$

A reiterada recusa governamental em promover a anistia política foi deplorada muitas vezes pelo católico Alceu - de forma especial, por meio de mensagens escritas para as Festas de dezembro, tempo tradicionalmente propício a atos de indulto e perdão emanados do poder público. ${ }^{19}$ Insistência que era motivo de orgulho da parte de nosso autor: "Há 12 anos, desde o Natal de 1964, que me bato pela anistia ou pelo perdão, pouco importa, aos nossos 'crimes políticos'.” (1977: 171; texto publicado na imprensa em 02/09/76.)

O quadro econômico, um dos orgulhos do regime (afinal, o Produto Interno Bruto expandia-se aceleradamente), é focado por Alceu através de lentes mais rigorosas. $\mathrm{O}$ autor da Crônica do Tempo Presente constata a existência "de uma elite superdesenvolvida e uma massa subnutrida" (1974: 71; 01/08/1968). Aqui, de certa maneira, Amoroso Lima antecipa a "Belíndia” (o Brasil como misto de Bélgica e Índia), imagem celebrizada pelo

\footnotetext{
${ }^{17}$ Quanto à defesa dos frades, cf. in AMOROSO LIMA, 1974: 172: "Cada um desses jovens dominicanos [...] há mais de um ano estão sendo vítimas de um processo kafkiano". (S/d. Provavelmente por falha na edição, não há indicação precisa da data de publicação original deste texto. Pode-se presumir que ele seja do ano de 1971 já que, nessa obra - como em toda "Crônica do Tempo Presente" -, os artigos são dispostos em ordem cronológica e o texto está colocado entre os trabalhos de 1971.) Alceu também prefaciou a primeira edição do livro Cartas da prisão, onde um desses religiosos, Frei Betto (Carlos Alberto Libânio Christo), relata seus anos de cárcere, de 1969 a 1973. A reedição de Cartas da prisão (2008) mantém parte do prefácio original em sua $4^{\text {a }}$ capa.

${ }^{18}$ Cf. in SERBIN, 2001: 43.

${ }^{19}$ Cf. in AMOROSO LIMA, 1968: 32 e 36 (textos publicados em janeiro de 1965) e in AMOROSO LIMA, 1974: 212-14 (janeiro de 1973).
} 
economista Edmar Bacha, para retratar situação semelhante. ${ }^{20}$ Diagnóstico que faz Alceu descrer do "badalado milagre brasileiro". ${ }^{21}$

Se o ufanismo do "Brasil grande", repetido incansavelmente pela propaganda governamental, é alvo de constante contestação, os festejos oficiais dos 150 anos da Independência brasileira, em 1972, encontram um articulista avesso a comemorações. Em outras palavras, no ápice daquilo que foi programado como exposição pública do sucesso do regime, Alceu resolve "atravessar" os discursos governistas autolaudatórios com sua ladainha particular. Ainda bem distante de 07 de setembro, ele assinala que

A melhor das comemorações desses históricos 150 anos, pelo Governo de 1972, seria o restabelecimento, entre nós, de nossa verdadeira independência, que só se operará de modo autêntico, pela volta a um estado de direito, em pleno jogo de suas liberdades cívicas e da participação real do povo no Governo de sua nação livre (1974 [18/02/72]: 187).

Mais adiante, é criticada uma das atrações da celebração, o translado dos restos mortais de Pedro I, de Portugal para o Brasil, onde seriam alvo de exposição pública em vários pontos do país: “Quanto à passeata cívica dos despojos de Pedro I, por todos os cantos do Brasil, tem qualquer coisa de funéreo e até mesmo de grotesco, que toca às raias do inverossímil” (AMOROSO LIMA, 1974 [24/03/72]: 195).

E Amoroso Lima evoca o exemplo de Francisco de Assis - que, segundo a tradição, teria impedido seus discípulos de festejar o martírio de alguns companheiros, enviados em missão entre infiéis, argumentando que a única forma adequada de memorialização dos mártires era imitá-los. E, voltando ao Brasil da ditadura, o ponto nevrálgico é tocado por Alceu:

Quanto à grande deficiência, nessa planificação festiva, é precisamente análogo àquilo que levou São Francisco de Assis a proibir a comemoração do

\footnotetext{
${ }^{20}$ Como assinalei, o trecho de Alceu em questão foi escrito em 1968. Já a famosa fábula de Bacha sobre Belíndia, uma Ilha imaginária localizada entre Ocidente e Oriente, colonizada por belgas e com mão-deobra vinda da Índia, foi publicada pelo jornal Opinião, em 1974. A (pequena) distância temporal não invalida o paralelo, posto que Amoroso Lima e Bacha viam e criticavam o mesmo quadro de acentuada desigualdade de renda existente no Brasil - a despeito do bom desempenho macroeconômico nacional alardeado pelo governo civil-militar.

${ }^{21}$ Cf. in AMOROSO LIMA, 1974: 219; coluna jornalística publicada em 12/02/73. Vale dizer que o dito "milagre brasileiro" foi desacreditado, por Alceu, em outros textos. Cf., p. ex., AMOROSO LIMA, 1974: 205 e 247 (colunas jornalísticas publicadas em 04/05/72 e 23/08/73) e em AMOROSO LIMA, 1977: 187 $(23 / 09 / 76)$
} 
martírio de seus monges. Para o sesquicentenário de um acontecimento único e máximo em nossa História, como a Independência, a comemoração mais condigna seria uma nova independência. Ora, esse reindependência só pode derivar de uma autêntica reconciliação nacional [... e o articulista propõe igualmente] a revogação pura e simples de todos os atos políticos em vigor, como o famigerado AI-5, que contradizem formalmente a nossa independência autêntica e coletiva como povo, e constituem obstáculo intransponível para que se comemore o nosso sesquicentenário com algum feito, como seria o de uma larga Anistia política [...] (AMOROSO LIMA, 1974: 195-96, grifos do autor).

Isso posto, Amoroso Lima conclui, cotejando, mais uma vez, a euforia governamental e o que via como necessidades do momento. Ele repudia as "[...] palavras, slogans, cartazes e papilotes contraproducentes, que no mínimo o vento leva. O sesquicentenário merece uma comemoração e não uma simples rememoração" (1974: 196). ${ }^{22}$

E, já passado o ano festivo, em coluna datada de 01 de fevereiro de 1973, Alceu lembra, com irreverência, "o chacoalhar de ossos imperiais", questionando a ausência de liberdade no país, situação que refletiria o pouco zelo das autoridades para com o espírito independentista (AMOROSO LIMA, 1974: 217).

\section{3) Alceu Amoroso Lima extramuros}

Como visto, na Crônica do Tempo Presente, Amoroso Lima retrata parte do duro cotidiano vivido sob ditadura. Nesta coleção de textos, primeiramente publicados na imprensa e após isso reunidos em livro, são assinaladas cassações e perseguições políticas, desaparecimentos de opositores ao governo estabelecido, banimentos e exílios forçados. Eventos, todos eles, que confirmam o caráter autoritário do regime iniciado em 1964. E, em meio a um país emudecido pela censura e no qual o ufanismo governista era língua corrente nos meios de comunicação oficiais e privados, Alceu vai entoando seu rosário de críticas e protestos, pedindo mudanças de rumo. Em contexto tenso, ele procede com cautela, aproveitando-se da limitada tolerância que as autoridades constituídas

\footnotetext{
${ }^{22}$ Cabe observar que, provavelmente, um erro de diagramação transformou em "papilote" a palavra "papelote".
} 
parecem lhe conceder. ${ }^{23}$ Atuação essa que, na sociedade civil, vai lhe valer reconhecimento de crentes e não crentes.

Reconhecimento expresso em palavras impressas. Como ocorreu em dezembro de 1973 - durante a presidência do general Médici, tempo no qual a repressão política foi mais acentuada -, quando a Revista Eclesiástica Brasileira (REB) saudou o octogésimo aniversário de Amoroso Lima, prestando-lhe homenagem em editorial assinado por Leonardo Boff. Texto que, construído em linguagem teologal, ilustra o que vem sendo dito nas presentes linhas. De início, Boff escreve que Alceu Amoroso Lima, como “cristão e teólogo leigo", percorria "os caminhos da fé auscultando no mundo a voz de Deus.” (BOFF, 1973: 819) O então frade franciscano acrescenta:

A geração jovem dos cristãos da última década conhecemos não tanto o Dr. Alceu crítico literário, o ensaísta, pensador e teólogo, mas o homem da martyria bíblica, a testemunha dos valores fundamentais do cristianismo e da verdadeira humanidade, da Verdade, da Justiça e da Liberdade. Há uma voz que se faz ouvir semanalmente com uma persistência profética. Serena mas corajosa. Contundente mas construtiva. Livre mas comprometida. Se crer não significa apenas entregar-se radicalmente ao Mistério de Deus, mas poder vivê-Lo na totalidade das manifestações do mundo e do homem, então podemos dizer que o Dr. Alceu se nos revelou como um mestre da fé (BOFF, 1973: 819).

\footnotetext{
${ }^{23}$ Ainda está por se investigar a estratégia do governo ditatorial relativa à atuação crítica de Amoroso Lima. Por que Alceu não foi calado? Mais: por que não foi detido como tantos outros opositores do regime? O fato de Amoroso Lima ter sido poupado é usualmente explicado por suas inserção social e popularidade. Segundo tal interpretação, obstaculizar a ação do intelectual cristão, ou mesmo prendê-lo, teria repercussão muito negativa na arena pública (até entre simpatizantes moderados da nova ordem). Outra explicação razoavelmente conhecida aponta para Roma. Alceu, desde os anos 1950, era interlocutor e amigo de Giovanni Battista Montini, alto prelado curial que, a partir de 1963, assumira o trono de Pedro, com o nome de Paulo VI. Desta forma, atingir Amoroso Lima seria atingir o próprio pontífice reinante. São explicações que, embora plausíveis (não sendo também excludentes), jamais foram documentalmente provadas. Por fim, cabe apontar uma última tentativa de explicação, válida apenas para o período inicial do arbítrio. Em entrevista, o cardeal Arns afirmou ter ouvido, em missa pela alma de D. Argentina, esposa do Marechal Castelo Branco, morta em 1963, da parte de membro da família, que o presidente Castelo proibira os órgãos de repressão de molestarem Amoroso Lima. (ARNS, 2000). Seja como for, caberia igualmente investigar o alcance desta(s) proteção(ões) aparentemente gozada(s) por Amoroso Lima. Se é verdade que ele jamais foi submetido à prisão (ao contrário do que ocorreu com Heráclito Sobral Pinto, advogado de presos políticos e católico bem mais conservador que Alceu, na noite seguinte à decretação do AI-5), a consulta da correspondência entre Amoroso Lima e sua filha Maria Teresa lança dúvidas sobre a pretensa imunidade concedida ao líder leigo, ao menos no que tange à censura. No referido epistolário, Amoroso Lima assinala, em várias ocasiões, que alguns de seus textos não foram publicados pelo Jornal do Brasil ou pela Folha de S. Paulo. Em certos casos, fica claro que a censura foi ato interno da redação do jornal. Noutras ocasiões, todas ocorridas após a imposição do AI-5, não se pode identificar o responsável pela ordem de não publicar a coluna de Amoroso Lima. Para detalhes, ver Diário de um ano de Trevas, edição recente das cartas trocadas entre pai e filha Amoroso Lima, entre dezembro de 1968 e fevereiro de 1970.
} 
Declaração que ilustra bastante bem o que se está a dizer: o crente Alceu Amoroso Lima é reconhecido como alguém inserido no século ("na totalidade das manifestações do mundo e do homem"). E que é admirado ("se nos revelou um mestre da fé") por seu testemunho (no grego antigo usado por Boff, "martyria"). Atuação veiculada por suas colunas de jornal ("voz que se faz ouvir semanalmente"). Artigos que dão visibilidade a seu autor entre os mais novos (“geração jovem”). E, através da indicação cronológica dada pelo editor da REB (Boff destaca a ação de Amoroso Lima na "última década"), confirma-se que os artigos dos quais se está a falar são aqueles que compõem a Crônica do Tempo Presente.

Embora Leonardo Boff privilegie a projeção de Amoroso Lima entre os cristãos, Alceu consolidava a imagem de um fiel inserto nos dramas do século para além dos muros da Igreja.

É o que atestou, por exemplo, o tablóide O Pasquim poucos anos antes da REB homenagear Alceu (mas quando os brasileiros já viviam os tempos de maior repressão política). Em setembro de 1969, o irreverente jornal trouxe em suas páginas longa entrevista com o intelectual católico, reproduzida depois em livro (AMOROSO LIMA, 1984: 92-132). ${ }^{24} \mathrm{E}$ o apresentou aos leitores nos seguintes termos: “[...] Alceu merece admiração e o respeito unânime de todo mundo neste país, amigos ou inimigos, crentes ou não, por sua integridade intelectual, sua rigorosa honestidade e sua lúcida coragem." (AMOROSO LIMA, 1984: 92.)

Veículos tão diversos - a Revista Eclesiástica Brasileira e O Pasquim -, constatações convergentes: neles, Amoroso Lima é posto à vista como alguém que granjeou o respeito na esfera católica e fora dela, em boa parte por seu comportamento durante os chamados "anos de chumbo".

Comportamento que fez Henrique de Souza Filho, o Henfil, registrar também nas páginas de $O$ Pasquim:

No meu torrão só tem bonecas. E nestas bonecas estão incluídas o Jorge Amado (agora só anda nas colunas sociais, Jorginho?) e o Carlos Drummond

\footnotetext{
${ }^{24}$ A entrevista "Uma aula do Doutor Alceu" foi veiculada nos números 13 e 14 de $O$ Pasquim, em 18 e 25 de setembro de 1969 e, posteriormente, publicada no livro Memorando dos 90, obra póstuma que homenageou o pensador católico por ocasião de seus 90 anos, com extensa reunião de textos e depoimentos amorosianos compilados por Francisco de Assis Barbosa (Nova Fronteira, Rio de Janeiro, 1984). Retornando à entrevista originalmente concedida por Alceu a $O$ Pasquim: tal depoimento foi classificado, pela Redação do periódico carioca, como "a entrevista mais séria que já trouxemos para nossas páginas" (cf. in AMOROSO LIMA, 1984: 92).
} 
de Andrade (aquele que só escreve 10\%; nos 90\% restantes, fala de lebres, palmeiras e trocadilhos colegiais). Não falei que torrava o gênio, Ziraldo? Tem tanta gente tão boazinha, tão comportadinha e tão prestativa que alguns deveriam até colocar luzinha vermelha na porta de casa e a tabuleta 'Familiar'. Mas no meu torrão tem um macho! E agora vão entender por que o Jorge Amado (de hoje) e o Drummond são de fritar bolinhos: o macho é Alceu Amoroso Lima. É ler no JB pra confirmar (MORAES, 1996: 130-131). ${ }^{25}$

Enfim, tendo por marca a inequívoca oposição ao governo de então, a coluna de Alceu na imprensa tornou-se "ponto de encontro" referencial para certo público letrado, com leitores (e admiradores) muito plurais. De novo: se, na Crônica do Tempo Presente, Alceu abordou temas diversos, algo comparável a uma polifonia, pode-se propor que, no mesmo conjunto de escritos, o cantus firmus amorosiano foi a crítica ao arbítrio imposto ao país. E, se a imagem musical vale, tal melodia foi ouvida e apreciada por muitos.

Ao recordar a presença de Amoroso Lima no cenário brasileiro de então, o jornalista Zuenir Ventura sintetiza o que estava em jogo:

[Alceu] é o grande ícone daqueles tempos, o paladino da liberdade [...] uma leitura obrigatória. Era a grande referência, referência política [...] era uma pregação libertária. Acho que os artigos dele eram referência porque, primeiro, eles surpreendiam pela originalidade. [...] Ele lia os acontecimentos. Naquela época, eram acontecimentos vertiginosos, o mundo mudava, um mundo em mutação, mutação permanente (VENTURA, 2000).

Atente-se, em primeiro lugar, para expressão utilizada por Ventura: Alceu como alguém que "lia os acontecimentos". Em termos análogos, Boff exaltara Alceu por seu empenho na interpretação dos tempos correntes, leitura empreendida a partir de sua crença religiosa. A afirmação de Boff, já disposta em parágrafo precedente, é formulada em linguagem confessional. Para Boff, Amoroso Lima trilhava "os caminhos da fé auscultando no mundo a voz de Deus". Observe-se que a utilização do verbo "auscultar" aponta para sentido preciso. Segundo certa tradição cristã, a escuta interior ou ausculta é entendida como espécie de ouvir potencializado, exercício que o crente, à luz da fé, deve

\footnotetext{
${ }^{25}$ Originalmente, o texto de Henfil foi publicado em $O$ Pasquim $\mathrm{n}^{\mathrm{o}}$ 140, de 7 a 13/3/72.
} 
realizar para divisar a vontade divina. Vontade essa que, uma vez discernida, informaria, conduziria, a ação do mesmo fiel. ${ }^{26}$

Acrescente-se que o próprio Amoroso Lima fez menção ao verbo "auscultar" na Crônica do Tempo Presente, adaptando tal exercício de escuta profunda ao que pensava serem as demandas do seu cotidiano. Em coluna intitulada "Mocidade Traída", de outubro de 1975, ele disse haver um fosso entre o regime repressor e os mais jovens. ${ }^{27}$ Advogou, então, a necessidade de "auscultar essas faixas intermediárias". E enfatizou: "auscultar o descontentamento, o desânimo, a vontade de 'fazer alguma coisa' " da mocidade de então (cf. todas as citações in AMOROSO LIMA, 1977: 66). Enfim, Alceu - que, aliás, se fizera oblato beneditino nos anos 1950 -, ao utilizar linguagem característica do universo religioso no qual transitava tão bem, fornece pistas para se entender o movimento operado na Crônica do Tempo Presente. Isto é, definindo sua atitude para com o século e seus agentes sociais como de "ausculta", ele ilustra sua postura de inserção no mundo, engajamento em clave cristã e progressista.

Atitude e inspiração, seja frisado, que o conduzem a dialogar com os novos tempos, com a modernidade, tratando de suas múltiplas facetas, como a leitura de toda a Crônica do Tempo Presente pode provar. Inserção no século que também leva Amoroso Lima a protestar seguidamente contra o governo civil-militar em seus escritos.

Exemplo emblemático da aceitação de Amoroso Lima como importante ator na luta pela redemocratização do país foi dado por Encontros com a Civilização Brasileira, revista associada à editora Civilização Brasileira. ${ }^{28}$ Tal periódico, em dezembro de 1978 , publicou número especial, marcando o 85 ${ }^{\circ}$ aniversário de Amoroso Lima. Neste volume, foram reunidos personagens de destaque no cenário nacional, objetivando saudar a atuação do veterano intelectual cristão na praça pública, sobretudo pela imprensa, durante o longo período de exceção que então vivia o país.

O tributo foi capitaneado pelo diretor do periódico em lume, Enio Silveira, conhecido por sua vinculação com o Partido Comunista. Da homenagem participaram cristãos e não-crentes. Entre aqueles, D. Paulo Evaristo Arns, cardeal arcebispo de São Paulo, dos mais destacados adversários do regime ditatorial entre a hierarquia eclesial; Leonardo Boff e Frei Betto, frades ligados à Teologia da Libertação; os homens de letras Otto Lara Resende e Otto Maria Carpeaux; o psicanalista Hélio Pellegrino. Já os que não

\footnotetext{
${ }^{26}$ Entendimento já presente na mais que milenar Regra beneditina. A respeito, ver PENIDO, 1997: 7.

${ }^{27}$ Coluna reeditada in AMOROSO LIMA, 1977: 66-67.

${ }^{28}$ Daqui em diante, o número de revista em questão será citado como VVAA, 1978.
} 
professavam fé religiosa eram representados pelo arquiteto Oscar Niemeyer, os intelectuais Antônio Houaiss e Nelson Werneck Sodré e pelo próprio Ênio Silveira. Todos, sem exceção, contrários ao governo estabelecido.

Carpeaux resume bem o que estava em questão: para ele, Alceu transformara-se em uma espécie de "bandeira": "Seus [de Amoroso Lima] artigos de jornal são lidos no país inteiro por um público que se pode avaliar em milhões de leitores" (VVAA, 1978: 269). Textos que propunham "um programa político e social do maior radicalismo" (VVAA, 1978: 269). Para Carpeaux, Alceu expressaria

[...] o anseio urgente do povo brasileiro de restabelecer - ou, melhor, de estabelecer a liberdade democrática dos seus cidadãos, dos seus partidos políticos, dos seus sindicatos de trabalhadores urbanos e rurais, da sua Igreja e da sua cultura. Por sua voz reivindica-se o direito do povo brasileiro de eleger livremente e diretamente seus governantes e seus legisladores, assim como convém a uma nação constituída em República. Pela voz de Tristão de Athayde exige-se o direito de todos os cidadãos brasileiros a um padrão de vida digno de criaturas humanas e exige-se a humildade de autoridades que existem para servir-nos em vez de dominar-nos conforme seu arbítrio e desmandos. Trata-se de implantar nesta terra o reino da Paz e da Justiça (VVAA, 1978: 269).

Já Niemeyer, após destacar no pensador cristão “[...] o homem superior que compreende seu tempo e nele se integra consciente e generoso" (VVAA, 1978: 250), disse ter o hábito de abrir "[...] o jornal na página em que escreve [Amoroso Lima], à espera da palavra desejada. Atento, na sua trincheira, Tristão de Athayde continua nesta luta pela liberdade que tão bem se harmoniza com seu Deus." (VVAA, 1978: 250).

Outros irão ainda mais longe na exaltação. Tome-se o caso de Ênio Silveira. Ao apresentar a homenagem da Civilização Brasileira, no tenso final do governo Geisel e no incerto prosseguir de sua mais que timorata abertura política, Silveira escreve:

Se Alceu não fosse naturalmente modesto, o que ainda mais acentua suas qualidades humanas e intelectuais, bem que poderia repetir a frase de Sir Christopher Wren, famoso arquiteto da era elisabetana: 'If you seek my monument, look around!' Não nos será necessário, porém, olhar em torno para 
descobrir o monumento a Alceu Amoroso Lima: ele é o próprio monumento (VVAA, 1978: 202. Grifos do autor.).

Um monumento construído, lapidado, pela militância progressista do renovado católico Alceu. ${ }^{29}$

\section{Considerações finais}

Cumpre sintetizar o aqui exposto. De celebrado líder da reação católica brasileira, na primeira quinzena/vintena de anos após sua conversão religiosa, tendo passado por significativa mudança eclesiológica e política, processo de câmbio decidido sobretudo na década de 1950, Alceu Amoroso Lima edificou outra imagem de si. Imagem difundida e consolidada publicamente, entre crentes e não-crentes, em virtude de sua aberta oposição à nossa mais recente ditadura civil-militar.

Identificado como importante porta-voz de valores democráticos, em muito devido às opiniões consignadas na Crônica do Tempo Presente, nosso autor foi saudado por múltiplas vozes de dentro e de fora dos muros eclesiais. Recepção positiva que autoriza a conclusão: por sua performance na imprensa e na Ágora nacionais, de meados dos anos 1960 até sua morte, ele uniu cidadãos muito díspares na mesma frente, na luta pelo retorno ao Estado de Direito.

Mais que isso, encerrando análise que se apresenta por histórica, é interessante frisar a origem e a história das palavras: no mais longo e obscuro período de arbítrio que se abateu sobre a nação, Alceu Amoroso Lima, atuando na praça pública em nome de sua fé, lembrou aos brasileiros o significado original da palavra católico: universal.

\section{Fontes}

AMOROSO LIMA, Alceu (1946). Carta aos Católicos de Maceió. A Ordem. Rio de Janeiro, ano 26, n. 8 e 9, pp. 250-255, ago./set. (1965). Pelo humanismo ameaçado. Rio de Janeiro: Tempo Brasileiro. (1968). A experiência reacionária. Rio de Janeiro: Tempo Brasileiro.

\footnotetext{
${ }^{29}$ Cumpre salientar que, neste período, a aclamação de Amoroso Lima por tão variadas personalidades teve sua contrapartida na oposição de grupos mais conservadores, que condenavam o câmbio eclesiológico e político operado por ele. Alceu mesmo reconhece: "Os tradicionalistas e os integralistas me consideram como um traidor." (AMOROSO LIMA, 1984: 116)
} 
(1973). Memórias improvisadas: diálogos com Cláudio Medeiros Lima. Petrópolis: Vozes.

(1974). Em Busca da liberdade. Rio de Janeiro: Paz e Terra.

(1977). Revolução suicida: Testemunho do Tempo Presente. Rio de Janeiro: Ed. Brasília/Rio.

(1984). Memorando dos 90: entrevistas e depoimentos coligidos por Francisco de Assis Barbosa. Rio de Janeiro: Nova Fronteira.

(1999). Revolução, reação ou reforma?. 2a. ed., Petrópolis: Vozes.

(2003). Cartas do Pai. São Paulo: Instituto Moreira Salles.

(2013). Diário de um ano de trevas. São Paulo: Instituto Moreira Salles.

ARNS, Paulo Evaristo Cardeal (2000). Entrevista concedida a Marcelo Timotheo da Costa. Arquivo privado.

BOFF, Leonardo (1973). Os 80 Anos de Alceu Amoroso Lima (Palavras da Redação). Revista Eclesiástica Brasileira. Petrópolis. Vol. 33, nº 132. pp. 819-825, dez.

MORAES, Dênis de (1996). O rebelde do traço: a vida de Henfil. 2a. ed., Rio de Janeiro: José Olympio.

PENIDO, Basílio (1997). A escolha de Deus: comentário sobre a Regra de São Bento. 2a. ed., Juiz de Fora: Mosteiro da Santa Cruz.

[Sem autor] (1936). Dieu, est-Il à Droite?. La Vie Intellectuelle. Juvisy, vol. 41, n. 1 e 2, pp. 49-72 e pp. 219-245, fev./mar.

VENTURA, Zuenir (2000). Entrevista concedida a Marcelo Timotheo da Costa. Arquivo privado.

VVAA (1978). Alceu: 85 anos: homenagem ao grande brasileiro. Revista Encontros com a Civilização Brasileira. Rio de Janeiro, vol. 6, no. Especial, pp. 202-320, dez.

\section{Referências Bibliográficas}

AARÃO REIS, Daniel (2014). Ditadura e democracia no Brasil. Rio de Janeiro: Zahar.

AARÃO REIS, Daniel et alii (2014). A ditadura que mudou o Brasil. Rio de Janeiro: Zahar.

ARRIGUCCI JR., Davi (1987). Enigma e comentário: ensaios sobre literatura e experiência. São Paulo: Cia das Letras.

COSTA, Marcelo Timotheo (2010). Brazil. In: PATTE, Daniel (Org.). The Cambridge Dictionary of Christianity. Cambridge: Cambridge University Press, pp. 140-148. (2006). Um itinerário no século: mudança, disciplina e ação em Alceu Amoroso Lima. São Paulo/Rio de Janeiro: Loyola/PUC-Rio.

. (2008). Uma curva no rio: as conversões de Alceu Amoroso Lima. Escritos. Rio de Janeiro, ano 2, n. 2, 2008, pp. 183-212.

LIBÂNIO, João Batista (2000). Igreja contemporânea: encontro com a modernidade. São Paulo: Loyola.

LÖWY, Michael (2000). A Guerra dos Deuses: religião e política na América Latina. Petrópolis: Vozes.

MAINWARING, Scott (1989). Igreja Católica e política no Brasil (1916-1985). São Paulo: Brasiliense.

MENOZZI, Daniele (1999). A Igreja Católica e a secularização. São Paulo: Paulinas.

NAPOLITANO, Marcos (2014). 1964: história do regime militar brasileiro. São Paulo: Contexto. 
SERBIN, Kenneth (2001). Diálogos na sombra: bispos e militares, tortura e justiça social na ditadura. São Paulo: Companhia das Letras.

DOI:10.12957/intellectus.2018.39092 